\title{
Chronic non-suppurative osteomyelitis with proliferative periostitis or Garre's osteomyelitis
}

\author{
Kaushal Mahendra Shah, Amol Karagir, Shridevi Adaki
}

Department of Oral Medicine, Diagnosis and Radiology, Bharati Vidyapeeth Deemed University Dental College, Sangli, Maharashtra, India

\section{Correspondence to} Dr Kaushal Mahendra Shah, thirty2creations@gmail.com

\section{DESCRIPTION}

The word 'Osteomyelitis' originates from the ancient Greek words osteon (bone) and muelinos (marrow) and means infection of medullary portion of the bone. It can be classified as acute, subacute or chronic, depending on the clinical presentation. ${ }^{1}$ The decline in prevalence can be attributed to the increased availability of antibiotics and the progressively higher standards of oral and dental health.

Garre's osteomyelitis is a distinctive type of chronic osteomyelitis associated with gross thickening of the periosteum of the bones and peripheral reactive bone formation resulting from mild irritation or infections. The condition is seen exclusively in children or young adults. Mandible is more affected than the maxilla. ${ }^{2}$

We report a 5-year-old child who visited our outpatient department with a painful right mandibular tooth, and a slowly progressive extraoral swelling involving the lower border of the mandible. Intraoral examination revealed a badly carious right deciduous mandibular second molar, which was tender on percussion, while the corresponding lower border of mandible on palpation exhibited a diffuse, non-tender, bony hard swelling. Localised ipsilateral submandibular lymphadenopathy was also evident. Based on these findings, a provisional diagnosis of a chronic alveolar abscess was made. However, an orthopantomograph taken to diagnose the cause and extent of the bony hard swelling revealed a typical periosteal reaction of the inferior cortex of mandible in relation to the infected deciduous mandibular second molar (figure 1). No other radiopaque or radiolucent foci were evident in the surrounding bone. The history of a slowly progressive swelling in a very young child, along with clinical findings of a bony hard, diffuse swelling with a carious tooth and typical radiological picture, led to the final diagnosis of osteomyelitis with proliferative periostitis or in other words 'Garre's osteomyelitis'. Treatment consisted of removal of the offending deciduous molar and administration of an antibiotic. Regression of the periosteal reaction is expected over a period of time without any need for surgical intervention.

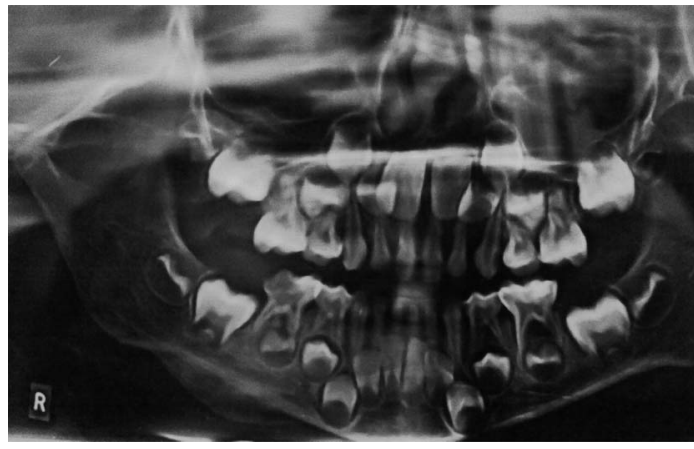

Figure 1 Orthopantomograph.

\section{Learning points}

- Garre's osteomyelitis is a non-suppurating type of osteomyelitis, with a reactive periosteal thickening due to a low-grade irritation or dental infection.

- There is no need for any surgical intervention for resolution of the periostitis, but just removal of the causative irritant, in this case, removal of the offending carious tooth.

- Osteoblastic osteosarcoma and Ewing's sarcoma, both should be included in the differential diagnosis, since sometimes these bone malignancies may also show laminated periosteal reaction, in young individuals.

Contributors All the authors contributed equally in preparing the manuscript.

Competing interests None.

Patient consent Obtained.

Provenance and peer review Not commissioned; externally peer reviewed.

\section{REFERENCES}

1 Baltensperger M, Eyrich G. Osteomyelitis of the jaws. Springer: Berlin, Heidelberg, 2008

2 Ellis DJ, Winslow JR, Indovina AA. Garre's osteomyelitis of the mandible: report of a case. Oral Surg 1977;44:183. 


\section{Images in...}

Copyright 2013 BMJ Publishing Group. All rights reserved. For permission to reuse any of this content visit http://group.bmj.com/group/rights-licensing/permissions.

BMJ Case Report Fellows may re-use this article for personal use and teaching without any further permission.

Become a Fellow of BMJ Case Reports today and you can:

- Submit as many cases as you like

- Enjoy fast sympathetic peer review and rapid publication of accepted articles

- Access all the published articles

- Re-use any of the published material for personal use and teaching without further permission

For information on Institutional Fellowships contact consortiasales@bmjgroup.com

Visit casereports.bmj.com for more articles like this and to become a Fellow 